\title{
El-Zuma Cemetery: Contemporary Threats to the Site
}

\author{
Jolanta Juchniewicz
}

The ancient cemetery in El-Zuma is liable to degradation due to the combination of natural factors and human activities. The following is a preliminary analysis of threats to the site and its monuments.

\section{Human Activity}

The cemetery in El-Zuma is located on the edge of a dynamically growing village, which is encroaching on the tumulus field and threatening its complete absorption. There was no protective fence around the excavation area until 2014, which made it vulnerable to uncontrolled human activity, including quarrying of the tumuli for building materials (see Chapter 2.1), and car traffic, with heavy vehicles generating strong ground vibrations.

\section{Natural Factors}

Climate change represents a relatively new contemporary natural threat to both the substructure as well as the superstructure of the tumuli. This situation arose after the construction of the Merowe Dam (Ahmed 2003, 252) on the Fourth Cataract, completed in 2009. The reservoir is $176 \mathrm{~km}$ long (Zaid, Shigidi, and Koll 2013, 1) and covers an area of c. $500 \mathrm{~km}^{2}$. Large reservoirs lead to an increase in humidity, resulting from surface evaporation and changes in the structure of precipitation within a belt around $100 \mathrm{~km}$ wide, extending outwards from the reservoir's shoreline (Degu et al. 2011). El-Zuma is only about $46 \mathrm{~km}$ away from the dam as the crow flies.

Laboratory tests have shown that the tombs are carved out in rocks characterized by a predominance of clay binder. The clay minerals contained in the binder, under the influence of water swell, can cause delamination, and as a consequence weaken the structure of the rocks. Rocks containing a larger amount of clay minerals are constantly damp because they do not dry out easily. Moistening of rocks can lead to spontaneous disaster (collapse of corridors, subsidence of shafts). The first major changes in soil moisture were noticed during the 2011 excavation season. It was then that the rock profiles of the tomb shaft in tumulus 9 subsided due to the high humidity of the freshly excavated structures [Fig. 5.1].

On the other hand, the tumuli, made from a mixture of earth, sand, and gravel, are exposed to erosion and when their surface layers become saturated with rainwater they flow downslope, typically as a continuous mass. In the summer, the mounds are worn away by the destructive force of abundant rainfall [Fig. 5.2].

Mining risks pose another serious danger. The tumuli in El-Zuma cover fairly extensive substructures. The vertical shafts and horizontal tunnels leading to them are carved out of rock. They can be compared to mine workings, although on a much smaller scale. The threat is of the same nature. The cross-sections of tunnels under type I mounds (see Chapter 3, in this volume) have the most unfavourable shape due to the mechanics of the rocks. The width of the tunnels is greater than their height, which causes very high tensile stress in the roof. This results in the detachment of parts of the roof layers, which can be observed under many tumuli in El-Zuma. Samples of rocks from which the tombs are hewn are characterized by extensive cracking, diversification of the petrographic composition, and, consequently, a high amplitude of overall strength, bulk density, porosity, and water absorption. This means inhomogeneous geological conditions, which makes it difficult to select appropriate protection measures to strengthen the excavated rock structures.

\section{Geotechnical Laboratory Tests of Rock Samples}

Prior to 2014, the El-Zuma excavation site had never been geologically examined. In that year seven rock samples (and one brick) were taken from the tombs and transported to Poland. The Foundation of Science and Mining Traditions at the AGH University of Science and Technology in Kraków was commissioned to perform geotechnical laboratory tests, including the determination of physical and mechanical parameters (bulk density, matrix density, porosity, water absorption, solubility, compressive strength). A lithological and mineralogical evaluation of rock samples was also carried out. The test results should be considered as indicative and preliminary. 


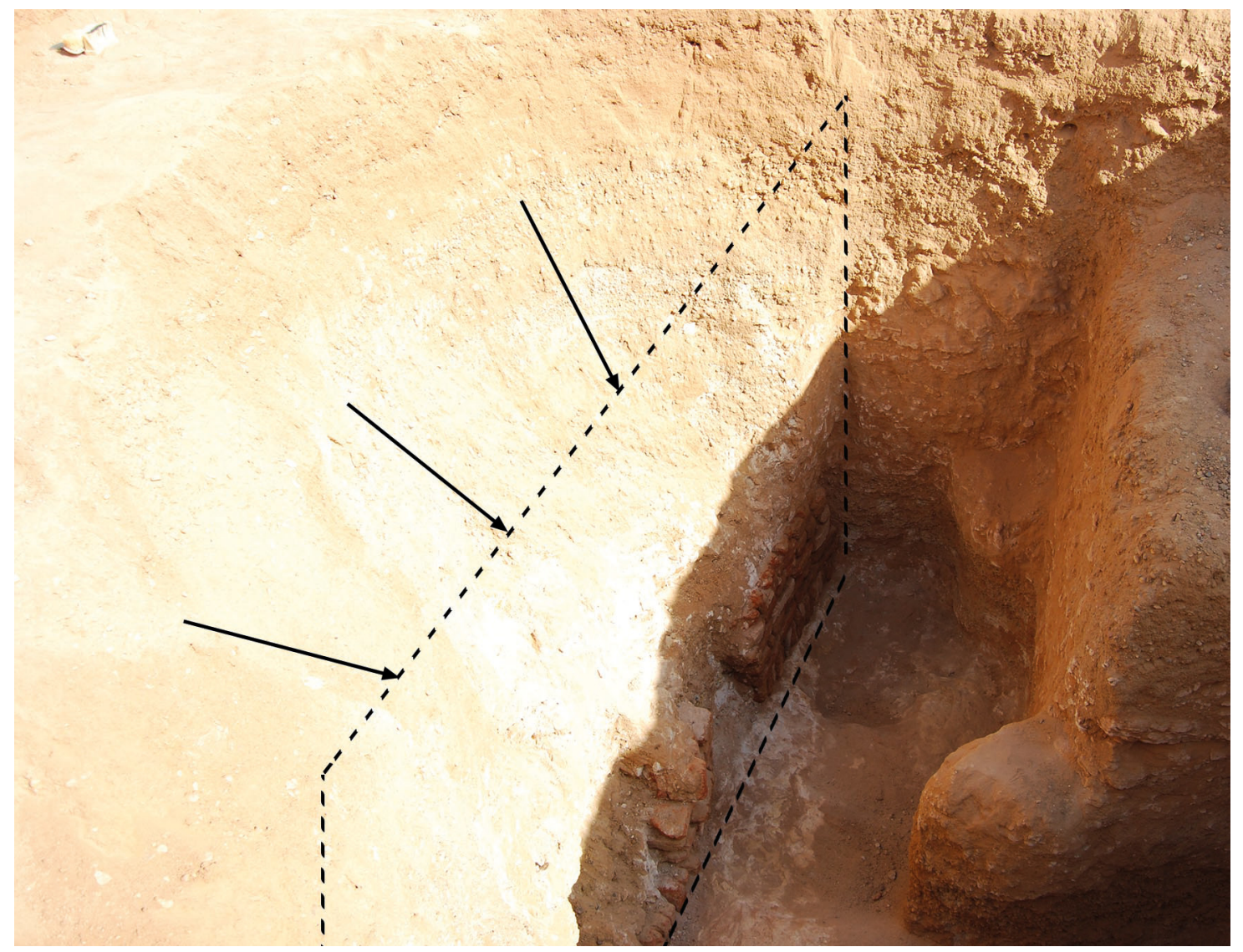

FIGURE 5.1 Tumulus 9, rock profile after landslide РНОТО вY Е. CZYŻEWSKA-ZALEWSKA

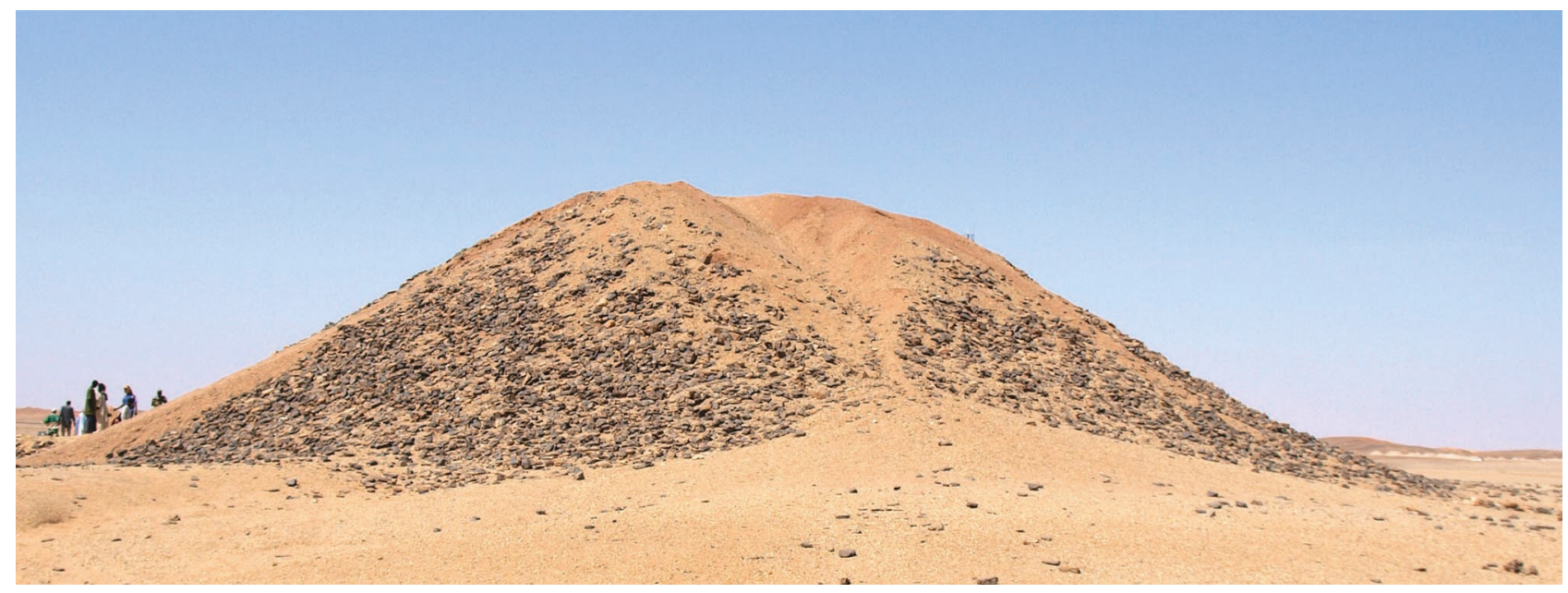

FIGURE 5.2 Tumulus 7, blurring of the superstructure PHOTO BY K. JUCHNIEWICZ

Rock samples were taken from two tumuli: from tunnel T.3 (D, F) and shaft T.26 (A, B, C, E, H). A brick from the blocking wall of T.26 is represented by sample G [Fig. 5.3]. 


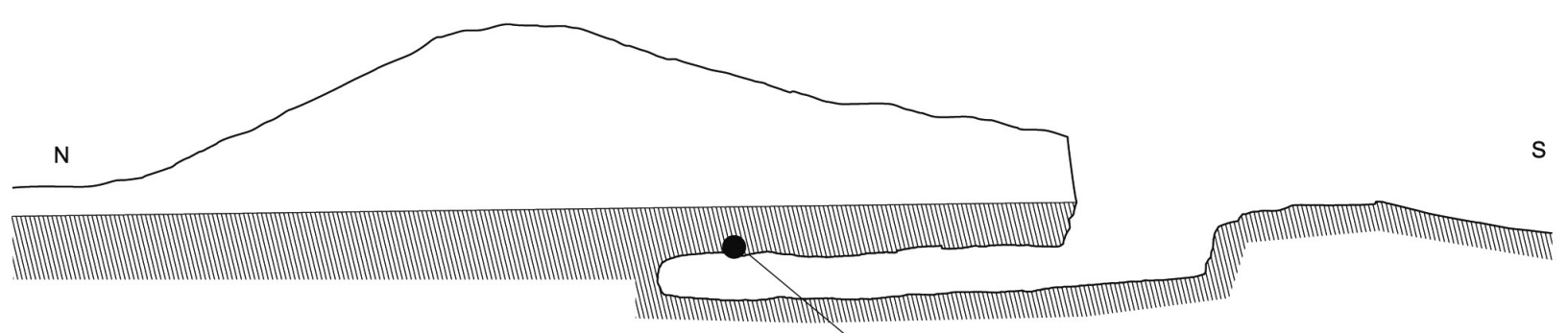

T.3
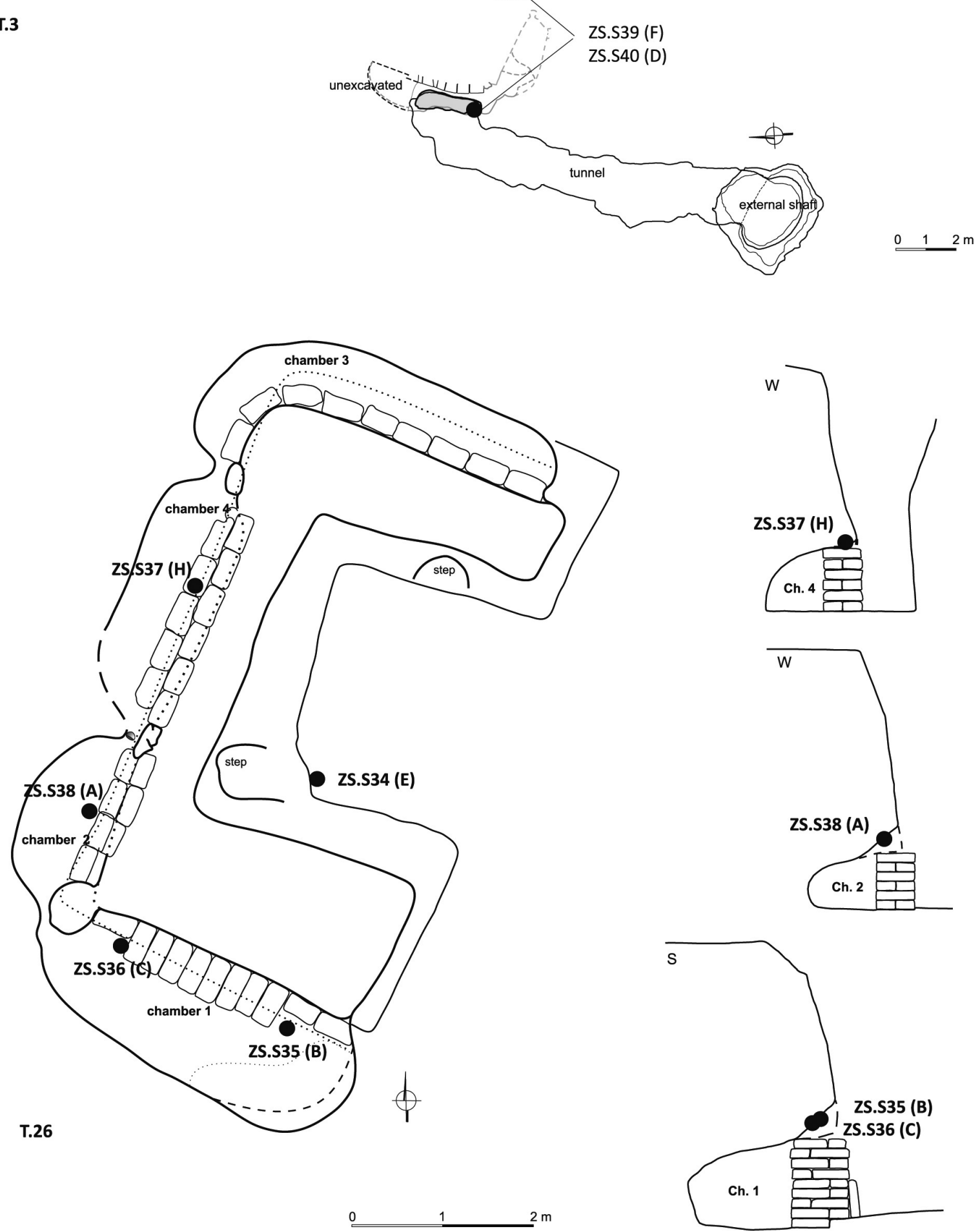

FIGURE 5.3 Locations from which samples were taken in tumuli 3 and 26

T.3 DRAWN AND DIGITISED BY J. JUCHNIEWICZ, T.26 DRAWN BY K. JUSZCZYK-

FUTKOWSKA, DIGITISED BY E. CZYŻEWSKA-ZALEWSKA 
TABLE 5.1 Test results: bulk density

\section{Symbol Number Type Bulk density $\left[\mathrm{g} / \mathrm{cm}^{3}\right]$ Average bulk density $\left[\mathrm{g} / \mathrm{cm}^{3}\right]$}

\begin{tabular}{|c|c|c|c|c|}
\hline \multirow{4}{*}{ A } & 1 & $\mathrm{R}$ & 2.00 & \multirow{4}{*}{2.03} \\
\hline & 2 & $\mathrm{R}$ & 2.00 & \\
\hline & 3 & $\mathrm{~N}$ & 2.07 & \\
\hline & 4 & $\mathrm{~N}$ & 2.04 & \\
\hline \multirow{4}{*}{ B } & 1 & $\mathrm{~N}$ & 2.72 & \multirow{4}{*}{2.82} \\
\hline & 2 & $\mathrm{~N}$ & 2.92 & \\
\hline & 3 & $\mathrm{~N}$ & 2.73 & \\
\hline & 4 & $\mathrm{~N}$ & 2.90 & \\
\hline \multirow{5}{*}{ C } & 1 & $\mathrm{R}$ & 2.01 & \multirow{5}{*}{1.98} \\
\hline & 2 & $\mathrm{R}$ & 1.94 & \\
\hline & 3 & $\mathrm{R}$ & 1.92 & \\
\hline & 4 & $\mathrm{~N}$ & 2.06 & \\
\hline & 5 & $\mathrm{~N}$ & 1.98 & \\
\hline \multirow{3}{*}{ D } & 1 & $\mathrm{R}$ & 1.53 & \multirow{3}{*}{1.63} \\
\hline & 2 & $\mathrm{~N}$ & 1.61 & \\
\hline & 3 & $\mathrm{~N}$ & 1.75 & \\
\hline \multirow{3}{*}{$\mathrm{E}$} & 1 & $\mathrm{R}$ & 1.63 & \multirow{3}{*}{1.61} \\
\hline & 2 & $\mathrm{R}$ & 1.54 & \\
\hline & 3 & $\mathrm{~N}$ & 1.66 & \\
\hline \multirow{3}{*}{$\mathrm{F}$} & 1 & $\mathrm{~N}$ & 1.73 & \multirow{3}{*}{1.71} \\
\hline & 2 & $\mathrm{~N}$ & 1.71 & \\
\hline & 3 & $\mathrm{~N}$ & 1.71 & \\
\hline \multirow{6}{*}{ G } & 1 & $\mathrm{R}$ & 1.44 & \multirow{6}{*}{1.47} \\
\hline & 2 & $\mathrm{R}$ & 1.41 & \\
\hline & 3 & $\mathrm{R}$ & 1.47 & \\
\hline & 4 & $\mathrm{R}$ & 1.45 & \\
\hline & 5 & $\mathrm{~N}$ & 1.56 & \\
\hline & 6 & $\mathrm{~N}$ & 1.49 & \\
\hline \multirow{4}{*}{$\mathrm{H}$} & 1 & $\mathrm{R}$ & 2.01 & \multirow{4}{*}{2.04} \\
\hline & 2 & $\mathrm{~N}$ & 2.07 & \\
\hline & 3 & $\mathrm{~N}$ & 2.05 & \\
\hline & 4 & $\mathrm{~N}$ & 2.01 & \\
\hline
\end{tabular}

THE FOUNDATION OF SCIENCE AND MINING TRADITIONS

3.1 Results of Geotechnical Laboratory Tests of Rock Samples ${ }^{1}$

3.1.1 Mineralogical Description

A a rock clay, pelitic grain-size structured;

B this is probably the top layer, the so-called "caliche," which is desert polish/toppings founded on the sandstone quartz carbonate;

C quartz sandstone with clay-ferrite binder;

D arcose sandstone with clay binder;

E arcose sandstone with clay binder;

1 Fundacja Nauka i Tradycje Górnicze 2014.
F arcose sandstone with clay binder;

G brick;

$\mathrm{H}$ a rock clay.

3.1.2 Physical and Mechanical Properties

Please see Tables 5.1-5.5. 
TABLE 5.2 Test results: matrix density

Symbol Number Matrix density $\left[\mathrm{g} / \mathrm{cm}^{3}\right]$ Average matrix density $\left[\mathrm{g} / \mathrm{cm}^{3}\right]$

\begin{tabular}{llll}
\hline & 1 & 2.66 & 2.66 \\
B & 2 & 2.67 & \\
& 1 & 2.84 & 2.85 \\
C & 2 & 2.86 & 2.62 \\
& 1 & 2.63 & \\
D & 2 & 2.62 & 2.55 \\
& 1 & 2.56 & 2.60 \\
E & 2 & 2.54 & 2.63 \\
& 1 & 2.61 & \\
F & 2 & 2.60 & 2.69 \\
& 1 & 2.63 & 2.65 \\
G & 2 & 2.62 & \\
\hline
\end{tabular}

THE FOUNDATION OF SCIENCE AND MINING TRADITIONS

TABLE 5.3 Test results: porosity

\begin{tabular}{lr}
\hline Symbol & Porosity [\%] \\
\hline A & 23.81 \\
B & 1.14 \\
C & 24.49 \\
D & 36.20 \\
E & 37.96 \\
F & 34.80 \\
G & 45.38 \\
H & 23.18 \\
\hline
\end{tabular}

THE FOUNDATION OF SCIENCE AND MINING TRADITIONS

TABLE 5.4 Test results: water absorption

Symbol Water absorption [\%] Average water absorption [\%]

\begin{tabular}{lrr}
\hline B & 1.60 & \\
& 3.21 & 2.40 \\
C & 11.09 & 10.65 \\
& 10.21 & \\
G & 23.87 & 24.21 \\
& 24.55 & \\
\hline
\end{tabular}

THE FOUNDATION OF SCIENCE AND MINING TRADITIONS 
TABLE 5.5 Test results: compressive strength

Symbol Number Compressive strength [MPa] Average compressive strength [MPa]

\begin{tabular}{llrl}
\hline A & 1 & $3 \cdot 39$ & 3.41 \\
& 2 & 3.43 & \\
$\mathrm{C}$ & 1 & 10.53 & 8.93 \\
& 2 & 9.23 & \\
$\mathrm{D}$ & 3 & 7.03 & 0.37 \\
$\mathrm{E}$ & 1 & 0.37 & 0.80 \\
$\mathrm{G}$ & 1 & 0.94 & 8.83 \\
$\mathrm{H}$ & 2 & 5.65 & 3.76 \\
\hline
\end{tabular}

THE FOUNDATION OF SCIENCE AND MINING TRADITIONS

\subsubsection{Compressive Strength}

Compressive strength is defined as the ratio of the sample to the destructive force of the compression surface. The study was performed on the testing machine's walter + bai.

\subsubsection{Solubility in Water after 24 Hours}

A solubility study was performed on samples in the form of a shapeless mass of about $100 \mathrm{~g}$. Samples were placed in a container and quenched with water. After 24 hours, the decomposition of the samples was examined in terms of quantity and quality.

- A and $\mathrm{H}$ - completely dissolved into silt.

- D, E, F-absorbed water and when they were being removed from the container, they disintegrated into smaller pieces.

- B, C, G - they did not disintegrate under the water, but were only saturated with water.

\subsection{Summary}

Laboratory tests show that the samples represent rocks of very loose compactness, of sedimentary origin, mainly sandstones, clay-bonded clay, of low compressive strength, with little resistance to weathering processes, especially under the influence of water. Samples are characterized by diversified petrographic composition, which results in a high amplitude of strength results, bulk density, total porosity, and absorbability. This means inhomogeneous geological factors. 